\title{
Proučevanje povezave med etnično raznolikostjo in javnim prostorom: bibliometrična analiza
}

Mehanizem javnega - tj. posameznikov v družbi in njihovih medsebojnih odnosov - je najbolje razviden iz bistvene prvine mest: javnega prostora. Do zdaj je bilo o tem opravljenih mnogo obsežnih raziskav na najrazličnejših področjih. V članku avtorici predstavita konstruktivno analizo raziskovalnih pristopov in metodologij, uporabljenih pri proučevanju etnične raznolikosti kot družbenega pojava $v$ povezavi z javnim prostorom. Analizirali sta 1.079 raziskovalnih člankov, objavljenih med letoma 1995 in 2020 ter vključenih v informacijski sistem Web of Science. Bibliometrične podatke sta ročno filtrirali, scientometrično vizualizacijo pa sta izdelali v programu CiteSpace. Proučili sta, kako so uporabljene teoretične podlage, ter predstavili trenutne trende, vrzeli in pogoste metodološke pristope $\mathrm{v}$ analizirani literaturi, ki lahko prinašajo nova spoznanja, uporabna za nadaljnje multidisciplinarne raziskave. Izsledki njune raziskave razkrivajo dva osnovna načina teoretičnega pojmovanja obravnavane teme: pristop, ki se osredotoča na odnos med človekom in krajem ter temelji na proučevanju urbanistične in socialne politike, ter pristop, ki se osredotoča na odnose med ljudmi ter obravnava javni prostor kot dejavnik, ki te odnose omogoča.

Ključne besede: bibliometrična analiza, CiteSpace, etnična raznolikost, javni prostor, Web of Science 


\section{Uvod}

Ena najizrazitejših posledic globalizacije so čedalje pogostejše migracije in $s$ tem čedalje večja raznolikost urbanih naselij. Mnoga večja mesta se nenehno soočajo s prihodom priseljencev $\mathrm{z}$ raznih celin ter se spreminjajo $\mathrm{v}$ dinamična, heterogena in večkulturna mesta $\mathrm{z}$ najrazličnejšimi etničnimi skupinami in subkulturami. Etnična raznolikost je tako v družbeni kot prostorski obliki razvidna od (pod)nacionalne ravni do ravni sosesk. Etničnost označuje skupne značilnosti skupin ljudi ter njihove tradicije, ideologije in navade, ki naj bi se neprekinjeno prenašale skozi čas (Hutchinson in Smith, 1996; Peoples in Bailey, 2011). Ljudje se prej ali slej pridružijo drugim, ki imajo enake norme in vrednote, pri čemer nekatere skupine razvijejo posebne lastnosti. Kljub temu so danes bolj kot kdaj koli prej posamezniki in skupine prisiljeni v medsebojne odnose in deljenje prostora. Opisani pojav je že od nekdaj predmet raziskav na najrazličnejših področjih, kot so geografija, urbanizem, sociologija, okoljska psihologija in kulturologija. Odločilno vlogo pri oblikovanju odnosov med etničnimi skupinami ima mestno tkivo. Vsakodnevna interakcija med etničnimi skupnostmi poteka na skupnih prostorih v mestu. Javni prostor je zbirališče različnih identitet ali, kot navaja Sennett (2003), kraj, na katerem se srečujejo in spoznavajo neznanci. Skupen prostor je od nekdaj krhka prostorska prvina, ki jo ljudje oblikujejo z medsebojnimi odnosi. Poleg tega posameznikova kulturna identiteta ustvarja občutek pripadnosti kraju, $s$ čimer postanejo kraji za ljudi pomembni. Doživljanje skupnih prostorov takih, kot so, je mogoče prek njihove skupne rabe, opredelitve, razumevanja in izražanja (Stavrides, 2016). Uveljavljeni urbanistična teorija in praksa sta izrazito prodružbeno naravnani: spodbuja se druženje na odprtih javnih prostorih (Rishbeth idr., 2018: 37) na najrazličnejših stanovanjskih ravneh v mestu (Jacobs, 1961; Whyte, 1980; Gehl in Gemzoe, 1996; Carmona idr., 2003). Javni mestni prostor je tako kraj, na katerem vsakdanje prakse izražajo osebno in skupno kulturo družabnosti (Dines idr., 2006) ter je zato ključen za kakovost življenja prebivalcev. Kot navaja Hillier (1996), je etničnost ena najpomembnejših prvin mestnega prostora. Etnična raznolikost je zato družbena struktura, ki se oblikuje na podlagi stikov med skupnostmi v mestni krajini. Vzporedno z opisanim sociološkim vidikom so mesta prostori, ki so najbolje integrirani v prostorski sistem, privabljajo več pretoka ljudi, s svojo gravitacijsko silo pa omogočajo družbeno interakcijo (Hillier idr., 1993). V tem pogledu je pomembno razumeti vlogo etnične raznolikosti na javnih prostorih, glede na to, da so to prostori, ki so najbolj integrirani v mestni prostorski sistem. Etnične skupine so običajno prostorsko ločene druga od druge, hkrati pa stremijo k temu, da so čim bolj povezane v sistem (in z vsemi drugimi v njem). Kljub vsemu večina zaseda najbolj integrirane, manjšina pa sekundarne javne prostore $\mathrm{v}$ mestu (Ferati, 2009). Čeprav imajo hiše pripadnikov posameznih etničnih skupin enako zasnovo, prav njihova razporeditev $\mathrm{v}$ prostoru razkriva njihovo etnično pripadnost (Charambous Antoniadou in Peristianis, 2001). Z vidika družabnosti na javnih prostorih raziskave kažejo, da $\mathrm{z}$ večanjem etnične raznolikosti na njih potekajo tako procesi odtujevanja kot vzpostavljanja stikov (Blumer in Solomos, 2015). Izrazi javnega ali skupnega prostora (kot skupne lastnine posamezne skupine, ki simbolizira kolektivno identiteto) so način ustvarjanja skupnega prostora. Pravzaprav lahko skupni prostor postane predmet različnih reprezentacij, še preden je določen kot skupni prostor. Skupni prostori niso samo rezultat dejanj, s katerimi so bili ustvarjeni, ali dejanj, s katerimi so bili poimenovani. Zaradi različnih reprezentacij so lahko tudi napačno prepoznani, izolirani ali opuščni in celo prisvojeni na silo, zato je pomembno proučevati, kako lahko ljudje razvijejo orodja, $s$ katerimi lahko skupne prostore prepoznavajo, si jih zamislijo in o njih sanjajo (Stavrides, 2016).

Za boljše razumevanje opisane interdisciplinarne problematike je treba pregledati literaturo, iz katere so razvidni cilji, metodologije in kazalniki, ki so jih uporabili drugi raziskovalci, ter morebitne raziskovalne vrzeli na tem področju (Khoo idr., 2010). Ta pregled daje tudi podlago za obsežnejše raziskave izbrane teme. Na podlagi bibliometrične analize so Su idr. (2019) ugotovili, da konstrukcija družbenih modelov in njeno izražanje $\mathrm{v}$ javnem prostoru temeljita na konstrukciji nesnovne kulturne dediščine etničnih skupin. Kot navajata Shuangyun in Hongxia (2020: 27), akulturacija ni problem samo priseljencev, ampak tudi etničnih manjšin, ki že več generacij živijo v stiku z večinskimi skupinami. Andrade idr. (2016) so proučevali pravico do mesta in ugotovili, da se $\mathrm{v}$ zadnjem desetletju krepi segregacija na javnem mestnem prostoru. $\mathrm{Na}$ splošno številni raziskovalci ugotavljajo, da pri oblikovanju (ne)snovnih urbanih struktur in odnosov ne smemo podcenjevati vpliva etničnosti ali rase, hkrati pa je iz pregleda literature razvidno, da je bilo do zdaj opravljenih le malo bibliometričnih raziskav na to temo.

Predmet raziskave, predstavljene v tem članku, je povezava med etnično raznolikostjo in javnim prostorom, ki jo avtorici proučujeta na podlagi konstruktivne analize raziskovalnih pristopov in metodologij, uporabljenih v literaturi s tega področja. Avtorici opredelita konceptualne predpostavke in glavne trende $\mathrm{v}$ preteklem in sedanjem razvoju javnih mestnih prostorov $\mathrm{v}$ povezavi z etnično raznolikostjo. Obravnavata dinamiko in vzorce etnične raznolikosti na javnih mestnih prostorih, pri čemer predpostavljata, da etnična pripadnost vpliva na rabo javnih prostorov in odnose na njih. Njun cilj je potrditi ali ovreči tezo, da etnična raznolikost sama po sebi povzroča družbeno in prostorsko segregacijo na javnih prostorih. 
Preglednica 1: Iskalna merila za vključitev in izključitev ustreznih objav

\begin{tabular}{|c|c|c|c|}
\hline Merilo & Uporabljeni izrazi & & \\
\hline Poizvedba & $\begin{array}{l}\text { ethnic* } \\
\text { racial* } \\
\text { racism }\end{array}$ & + & $\begin{array}{l}\text { public space* } \\
\text { shared space* } \\
\text { urban space* } \\
\text { urban public space* } \\
\text { open space* } \\
\text { open public space* } \\
\text { common space* }^{*}\end{array}$ \\
\hline Prebivalstvo & Etnične skupine & & \\
\hline Lokacija & Odprti javni prostori, dostopni vsem & & \\
\hline \multirow{2}{*}{ Rezultati } & $\begin{array}{l}\text { Kvalitativni: mnenja in predpisi, povezani s tem, kako pripadniki etničnih } \\
\text { skupin uporabljajo javne prostore }\end{array}$ & & \\
\hline & $\begin{array}{l}\text { Kvantitativni: korelacija med etničnimi skupinami in uporabo javnih } \\
\text { prostorov }\end{array}$ & & \\
\hline Vrsta objave & Recenzirani članki, indeksirani v WoS & & \\
\hline Leto objave & $1995-2020$ & & \\
\hline
\end{tabular}

Opomba: Pri iskanju v WoS zvezdica * nadomešča od nič do neskončno poljubnih znakov.

\section{Raziskovalne metode in orodja}

\subsection{Iskanje in izbor}

Raziskava temelji na člankih, objavljenih med letoma 1995 in 2020 ter vključenih v bibliografsko podatkovno zbirko Web of Science (v nadaljevanju: WoS). Pri tovrstnih kompleksnih interdisciplinarnih raziskavah so zelo uporabna razna bibliometrična programska orodja, kot so CiteSpace, HistCite in VOSviewer (Shuangyun in Hongxia, 2020). Avtorici sta podatke analizirali ročno in s programom CiteSpace, ki se uporablja za vizualizacijo bibliometričnih podatkov na podlagi socitiranja in algoritmov za oblikovanje grozdov ter omogoča ustrezno proučevanje razvoja posameznega raziskovalnega področja (Chen in Song, 2019). Iskanje člankov na podlagi naslova, povzetka, podatkov o objavi, ključnih besed in obravnavane vsebine je potekalo julija 2021. Za posamezni članek so bili evidentirani naslednji podatki: naslov, podatki o avtorjih, podatki o reviji, povzetek, število citatov in število ogledov/prenosov. Pridobljeni so bili tudi drugi podatki, ki jih zagotavlja WoS, kot so avtorjeve ključne besede, ključne besede, ki jih samodejno ustvari WoS (KeyWords Plus), podatki o avtorjih in založbi, podatki o dokumentu ter citirani viri in literatura. Iskanje je potekalo $\mathrm{v}$ angleškem jeziku, pri čemer sta avtorici uporabili iskalni niz »'ethnic" OR 'racial*' OR 'racism' AND 'public space' OR 'urban open space' « ter druge podobne izraze, s katerimi sta odkrili ustrezne dodatne članke ter tako pridobili natančnejše in obsežnejše podatke (preglednica 1).

$\mathrm{Z}$ uporabljenimi izrazi in Boolovimi operatorji sta avtorici pri iskanju dobili 1.116 zadetkov (slika 1). Nato sta jih ročno

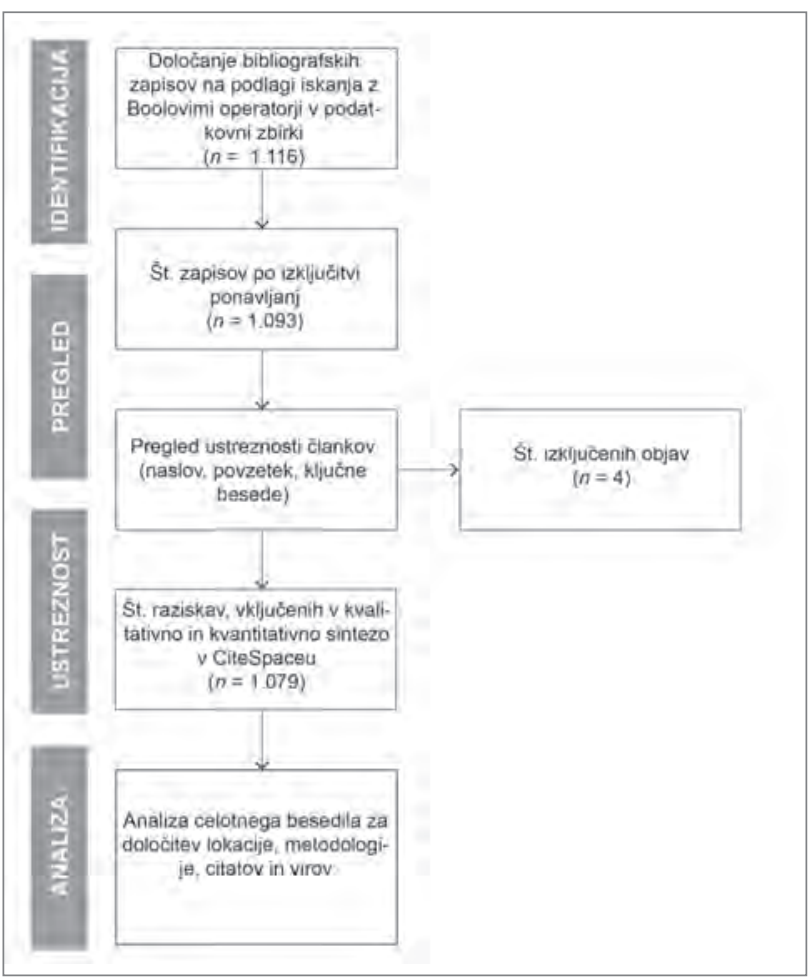

Slika 1: Diagram PRIZMA, ki prikazuje postopek izbora in analize podatkov (ilustracija: avtorici)

filtrirali, kar je pomenilo, da sta prebrali povzetke vseh objav, da bi izboljšali natančnost raziskave ter odkrili morebitna odstopanja in ponovitve. Na koncu sta izbrali 1.079 objav, relevantnih za raziskavo.

\subsection{Glavne omejitve}

Razlaga rezultatov na podlagi opisane metodologije ima več omejitev. Metode indeksiranja v WoS lahko zmanjšajo zanesl- 


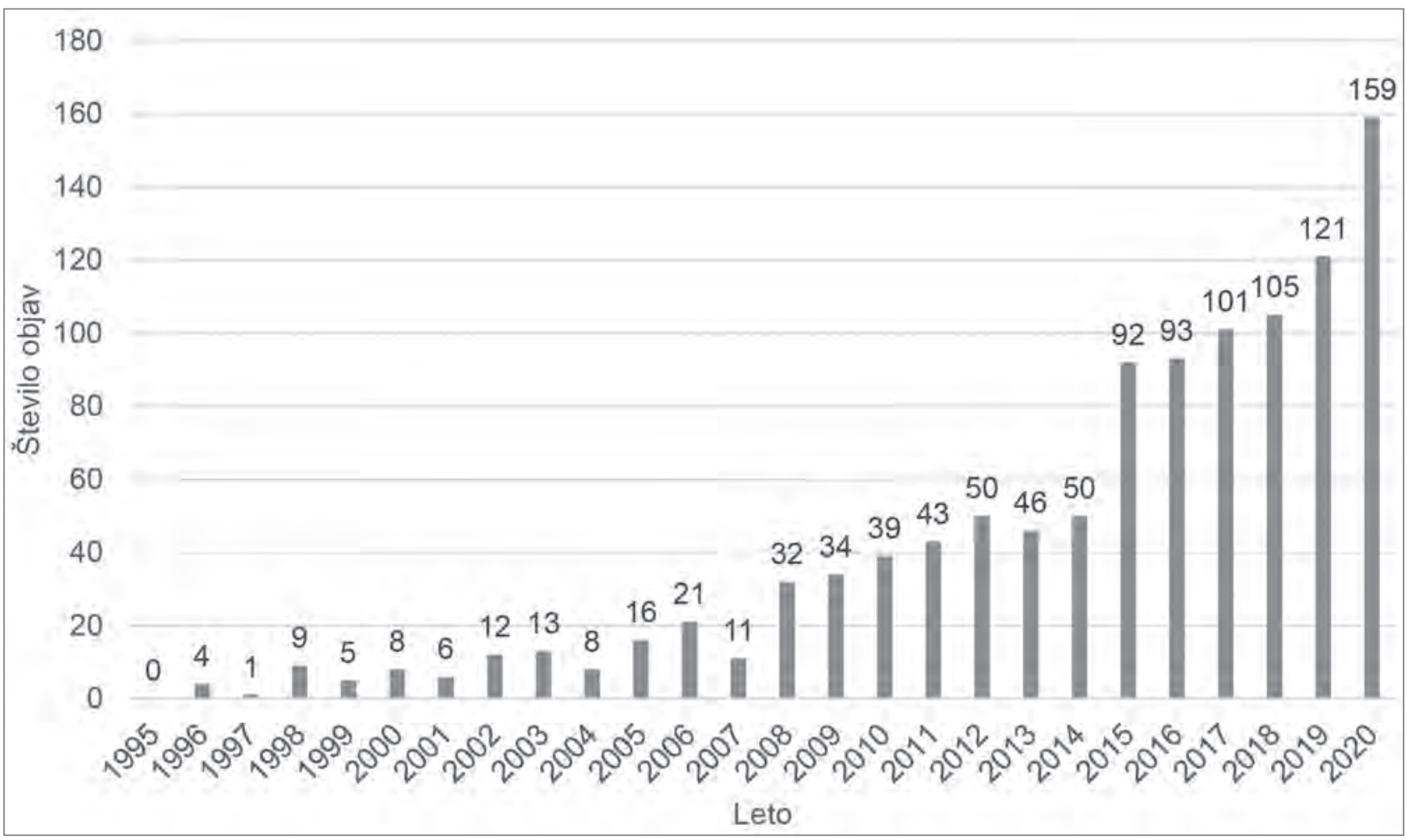

Slika 2: Razporejenost objav po letih (ilustracija: avtorici)

Preglednica 2: Raziskovalna področja, na katera spadajo izbrane objave

\begin{tabular}{ll}
\hline Raziskovalno področje & Frekvenca \\
\hline Geografija & 194 \\
\hline Urbanizem & 169 \\
\hline Sociologija & 134 \\
\hline Okoljske vede, ekologija & 120 \\
\hline Druga družboslovna področja & 112 \\
\hline Etnične študije & 102
\end{tabular}

jivost izsledkov. Seznam izbranih člankov o proučevani temi ni izčrpen in nedvomno je še več gradiva (npr. v revijah, knjigah in/ali poglavjih v knjigah, ki niso indeksirani v WoS, (ne)objavljenih poročilih, disertacijah in (ne)objavljenih zbornikih konferenc). Poleg tega se lahko tudi zadetki iskalnih poizvedb razlikujejo glede na to, katere ključne besede so vnesene $\mathrm{v}$ iskalni niz.

\section{Raziskovalni izsledki o povezavi med etnično raznolikostjo in javnim prostorom}

Avtorici sta na podlagi bibliografskih in geografskih podatkov, tematskih področij in metodoloških pristopov izbranih člankov podrobno proučili glavne teme in vzorce njihovega združevanja $\mathrm{v}$ grozde.

\subsection{Bibliografski in geografski podatki}

Na podlagi pregleda literature sta avtorici v WoS odkrili skupno 1.116 objav na temo etnične raznolikosti v javnem prostoru, po izključitvi podvojenih zadetkov pa je bilo na koncu 1.079 objav (96,7\%). Med njimi so prevladovali članki (93,4\%) in prispevki na konferencah (5,1\%). Čeprav je iskanje obsegalo obdobje 25 let (od leta 1995 do leta 2020), je bila polovica raziskav objavljenih šele po letu 2015 (slika 2). Skupno število citatov izbranih objav vidno narašča med letoma 2013 in 2020, vrh pa doseže leta 2020. Kljub vmesnim nihanjem je šstevilo objav v znanstvenih revijah sčasoma naraščalo, pri čemer je bila več kot polovica člankov objavljena v zadnjem desetletju. Navedeno dokazuje, da zanimanje za proučevano temo in število z njo povezanih raziskav čedalje bolj naraščata, pri čemer se tema proučuje na čedalje več raziskovalnih področjih. Večina del $(88,6 \%)$ je napisana v angleščini, med drugimi jeziki pa prevladujeta ruščina $(3,3 \%)$ in španščina $(3,2 \%)$. 
$\mathrm{V}$ preglednici 2 je prikazana razporeditev izbranih bibliografskih zapisov v raziskovalna področja, kot jo določi WoS. Večina objav je razvrščena v kategorijo »geografija «. Članki so bili objavljeni v več kot 150 revijah, od katerih pa se nobena ne osredotoča izključno na povezavo med etnično raznolikostjo in javnim prostorom. Revije spadajo $\mathrm{v}$ različne veje družboslovja, kot so sociologija, psihologija, socialna geografija, antropologija, urbanizem, arhitektura, prostorsko načrtovanje, politologija, jezikoslovje, ekonomija in zgodovina. Manjkajo samo najbolj uveljavljene revije s področja arheologije.

Izjemno veliko raziskav je bilo opravljenih v Severni, Srednji in Južni Ameriki (49,1\%), pri čemer večina obravnava (pred) mestna naselja in večetnične soseske v ZDA (40,2\%). Glavni poudarek je na mešanih soseskah, v katerih živijo belopolti in temnopolti prebivalci (Caliendo, 2011; Rollock idr., 2011; Gibson, 2018; Harwood idr., 2018), zlasti v New Yorku in Los Angelesu. Tovrstne raziskave se ukvarjajo predvsem s kulturno raznoliko rabo javnih in poljavnih prostorov, kot so šole in parki (Kaczynski idr., 2013; Vaughan idr., 2013; Trouille, 2014; Wilson, 2016; Rigolon in Németh, 2018), ter se osredotočajo na otroke in mladino.

Večji teroristični napadi, ki so v zadnjih 15 letih prizadeli Združeno kraljestvo in druge države, so vplivali na vsakodnevno razumevanje javnega prostora kot kraja, ki je lahko nevaren, ta nevarnost pa se pogosto povezuje z raso (Rishbeth idr., 2017: 42). Posledično je ena glavnih tem izbranih člankov globalni pristop k terorizmu po napadih 11. septembra 2001. Delež študij primera s tega področja, opravljenih v evropskih državah, je razmeroma velik (20,1\%). Od tega jih je bilo kar 14,4 \% opravljenih v Združenem kraljestvu, osredotočale pa so se na britanski medkulturni diskurz in etnografsko razumevanje etnično raznolikih sosesk. Izstopajo članki, ki obravnavajo večkulturnost ter integracijo muslimanskih manjšin in njihove vsakdanje aktivnosti na javnih prostorih (Schmidt, 2012; Kloek idr., 2013; Mohammad, 2013; Johnson in Miles, 2014; Hopkins idr., 2017; Joly, 2017). Nekatere študije primera proučujejo tudi kraje, na katerih je večkulturnost značilna že več stoletij. Številne raziskave se ukvarjajo z naselji v Palestini in Izraelu ter proučujejo področja konfliktov med Judi in Arabci, analizirajo nepriznana avtonomna območja in trenutno stanje $\mathrm{v}$ zatiranih skupnostih ter obravnavajo pojem kraja v večkulturnem kontekstu (Yiftachel in Yacobi, 2003; Shuval idr., 2009; Monterescu, 2011; Aharon-Gutmann, 2014; Jadallah, 2014; Badarin, 2015; Shtern, 2016; Omer idr., 2018; Rokem in Vaughan, 2018).

Raziskave obravnavajo tudi migracijske trende, pri čemer se $\mathrm{v}$ glavnem osredotočajo na občutek pripadnosti priseljencev $\mathrm{v}$ mestu ter na nasprotovanja med lastniki stanovanj in prišle- ki (Ryan, 2003; Ayata, 2008; Müller, 2011; Ehrkamp, 2013; Triandafyllidou in Kouki, 2013; Hall, 2015; Lobo, 2015; Demintseva, 2017). Opisano kaže, da je navedena tema v središcu vsakdanjih političnih razprav. Študije primera iz Azije in Avstralije se večinoma osredotočajo na etnično mešana območja, ki so posledica migracijskih tokov v bližnji ali daljni preteklosti. Williamson (2016) na primer proučuje, ali postajajo oblike pripadnosti kraju čedalje bolj prožne in ali je zanje značilna navezanost na več krajev hkrati. Raziskuje, kako se različne ravni pripadnosti kraju in mobilnosti prepletajo $\mathrm{v}$ procesih vključevanja priseljencev na etnično raznolikem in prehodnem predmestnem območju Sydneyja.

\subsection{Tematska področja}

Za boljše razumevanje strukture in dinamike znanstvenega področja je treba proučiti glavna raziskovalna področja, katere raziskave vsako področje vsebuje in kako so razna raziskovalna področja prek člankov med seboj povezana (Chen, 2020: 17). Iskanje je potekalo v dveh delih. Prvi del je temeljil na metodi analize pogostosti besed, pri čemer sta avtorici bibliografske zapise pregledali na podlagi ključnih besed. $S$ tem sta določili glavne teme člankov. Drugi del je temeljil na analizi socitiranja, ki ponazarja pogostost, $s$ katero sta dva članka skupaj citirana $\mathrm{v}$ tretjem (novejšem) članku. Rezultati analize socitiranja razkrivajo povezave med članki in posledično trenutne trende na posameznem znanstvenem področju.

Kot je razvidno iz grafa na sliki 3a, črti, ki ponazarjata pogostost ključnih besed javni in prostor, potekata vzporedno, kar pomeni, da so raziskave mestnih območij povezane z javnimi odprtimi prostori. Javni prostori pa se ne proučujejo samo na ravni celotnega mesta, ampak tudi na ravni sosesk, kar je razvidno iz precejšnjega števila raziskav, ki se osredotočajo na prostorsko segregacijo prebivalcev mestnih sosesk (slika 3b). Zsolt Farkas idr. (2017) so proučevali vplive in posledice prostorske segregacije Romov na območjih madžarskih mest. Burgers in Zuiderwijk (2016) sta raziskovala etnično segregacijo v Angliji in Walesu. Poleg javnih odprtih mestnih prostorov so se v smislu skupnega dobra proučevali tudi drugi kraji, kot so prostori, namenjeni delu, izobraževanju in preživljanju prostega časa. Kot navaja Eva Swyngedouw (2013: 293), se zaradi obstoječe prostorske segregacije v Čikagu ljudje različnih ras in družbenih razredov na rdeči liniji podzemne železnice L med seboj le redko srečujejo. Lobova (2014) je proučevala večkulturnost, kot jo med vožnjo na istem avtobusu v Darwinu v Avstraliji doživljajo trije posamezniki (aborigin, priseljenka in ona sama). Jacksonova (2019) je analizirala nasprotujoča si mnenja o kegljišču v Londonu, ki ga obiskujejo različne etnične skupine in mu grozi rušitev. Schmidtova (2015) je proučevala neenakost in raznolikost dostopa do šole na podlagi 


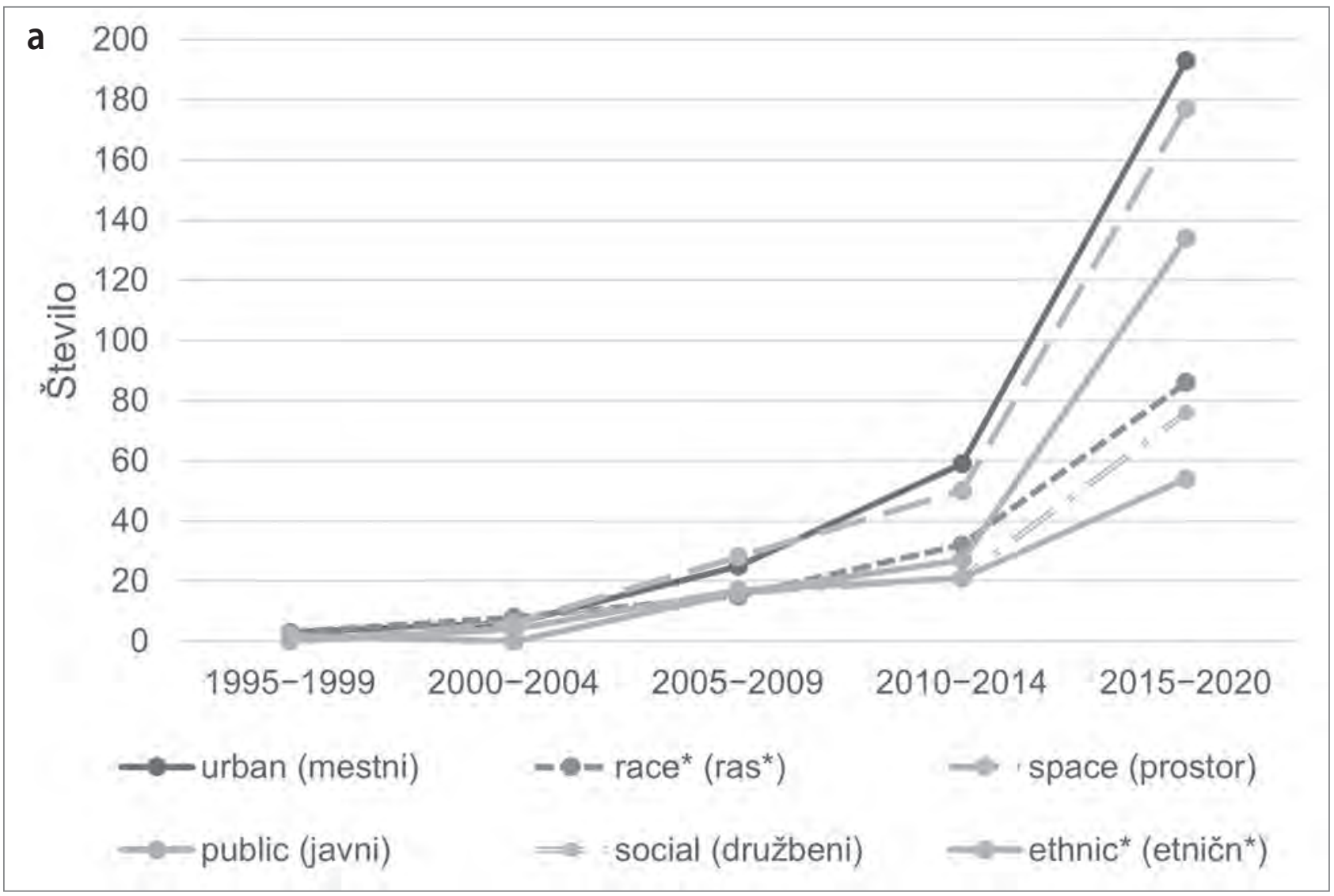

b 100

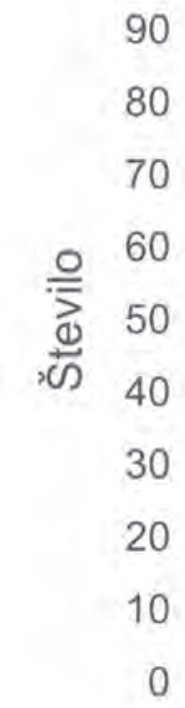

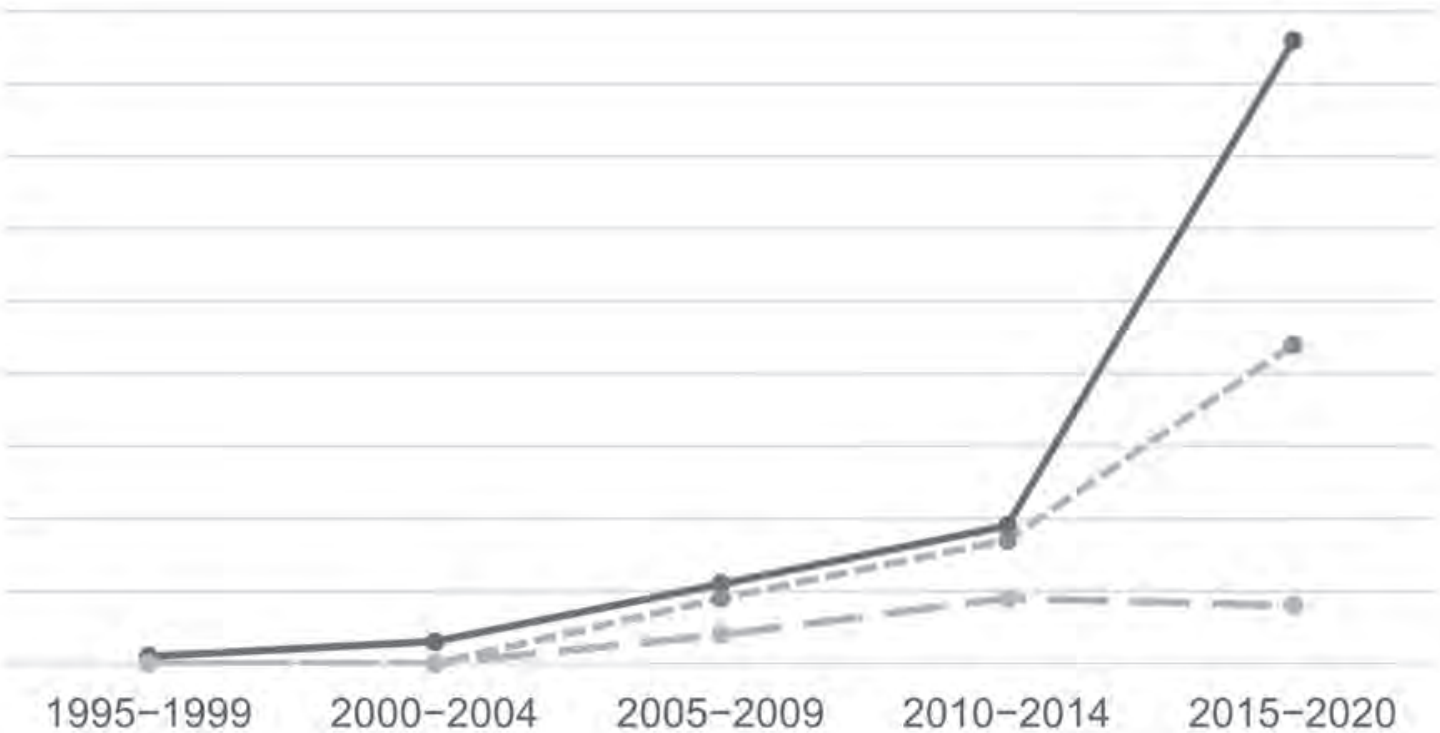

$\rightarrow$ public space (javni prostor)

- - urban space (mestni prostor)

$\rightarrow$ residential segregation (prostorska segregacija)

Slika 3: a) najpogostejše ključne besede v posameznem obdobju, b) najpogostejše besedne zveze v posameznem obdobju (ilustracija: avtorici) 


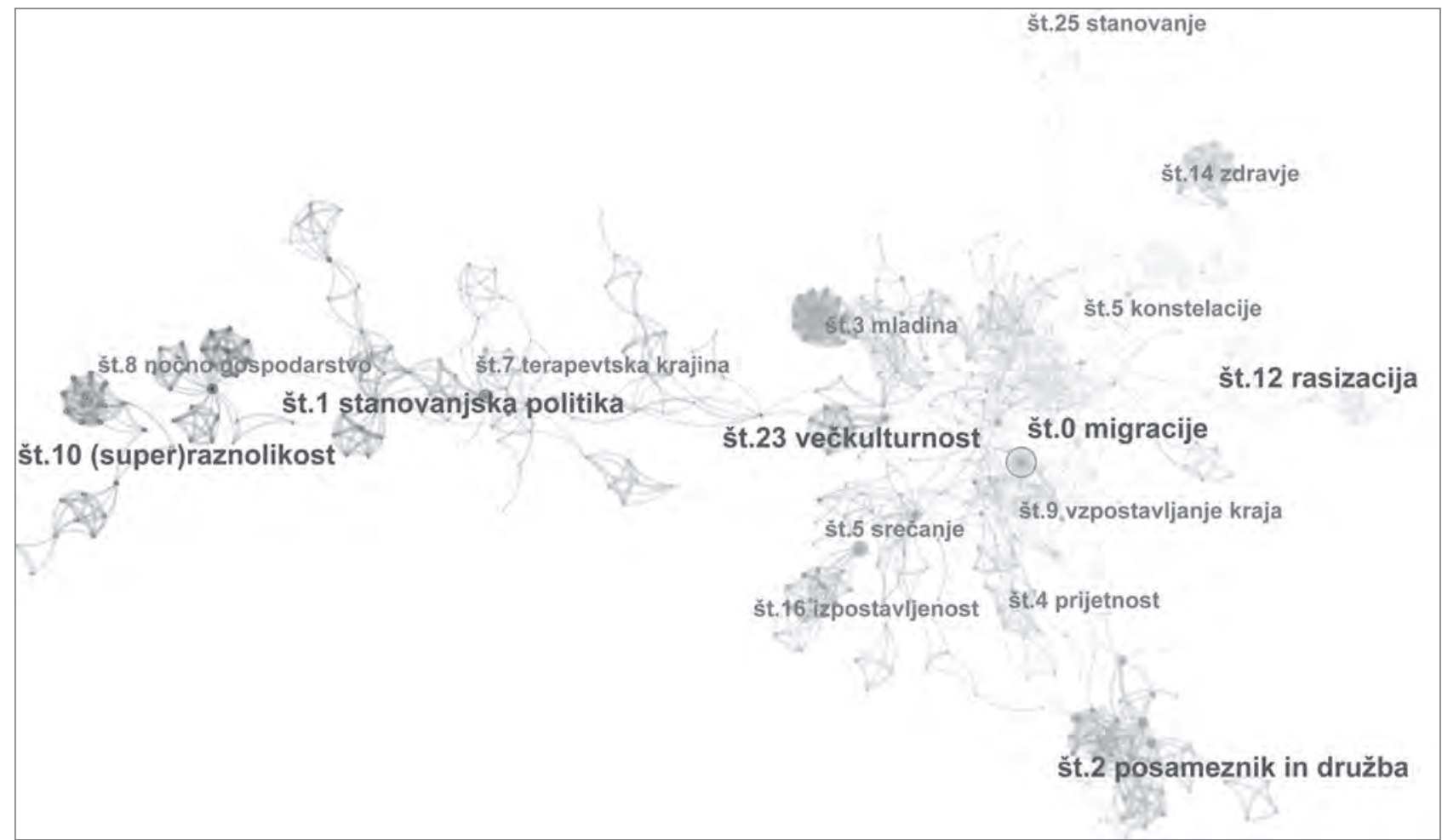

Slika 4: Grozdi, oblikovani v programu CiteSpace, s pripadajočimi temami (ilustracija: avtorici)

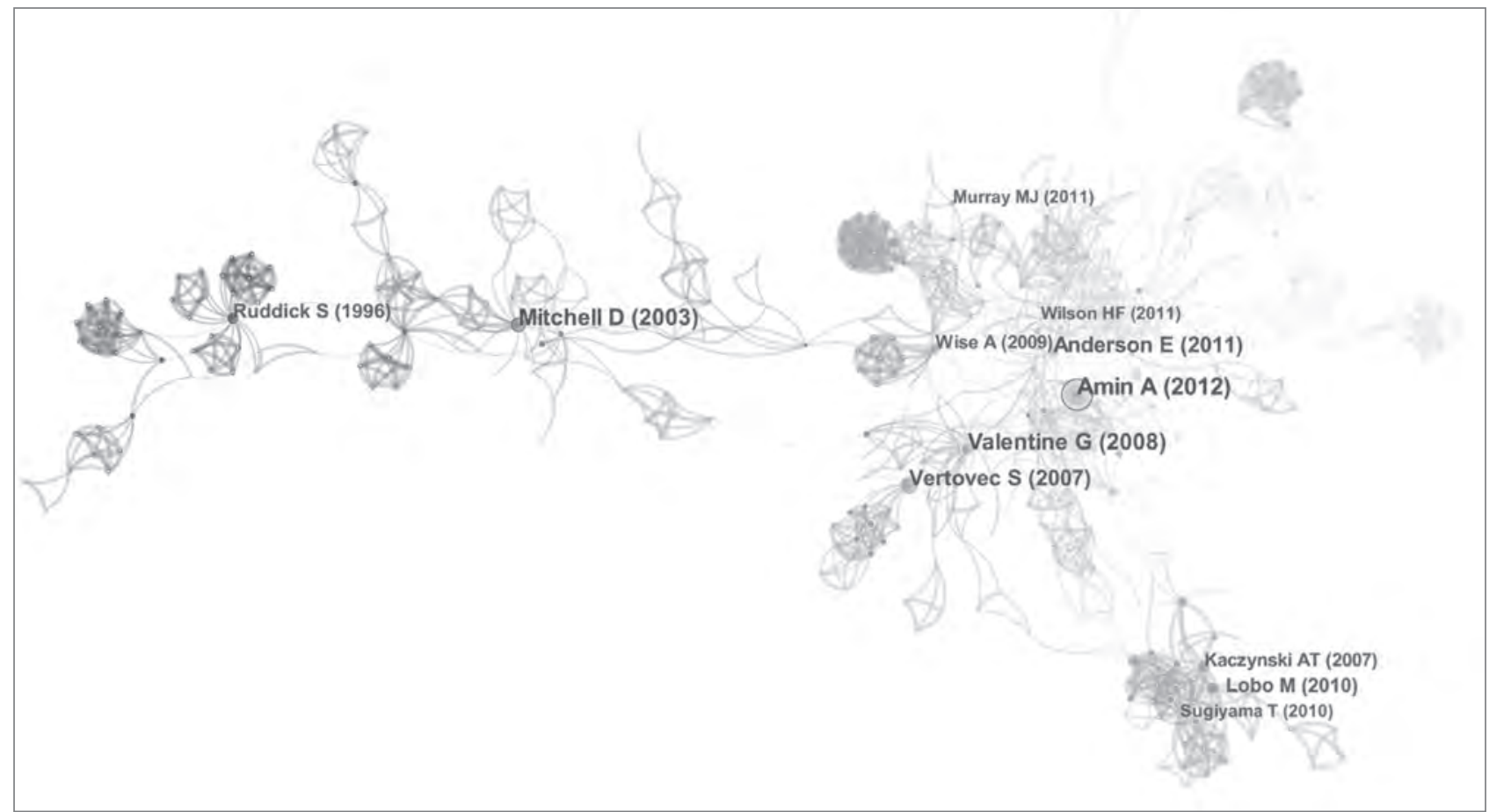

Slika 5: Mreža glavnih grozdov s pripadajočimi viri, oblikovana v programu CiteSpace (ilustracija: avtorici)

prostorskosti, pri čemer se je osredotočila na povezavo med družbeno organizacijo in prostorskim tkivom. Po drugi strani Yu idr. (2018) raziskujejo, kako študenti prostorsko dojemajo univerzitetno študentsko naselje v Memphisu. Članki različno razlagajo stopnjo prostorskosti in javnosti na javnem prostoru.
V preceǰ̌njem številu člankov $(44,6 \%)$ avtorji proučujejo različne parametre, povezane $\mathrm{z}$ etničnostjo, in kako lahko spodbujajo etnično raznolikost, pri čemer je glavni poudarek na neskladjih. Najpogostejši parametri, $s$ katerimi avtorji proučujejo povezavo med etnično raznolikostjo in javnim prosto- 
rom, so segregacija, integracija, vključevanje, izključevanje, stik, družbena interakcija in družbena kohezija. Navedeni parametri imajo večdimenzionalne pomene, saj se navezujejo na mesto kot fizično celoto $\mathrm{z}$ vso njeno dinamiko. Najpomembnejši parameter, segregacija, je bil na primer v mnogih raziskavah opredeljen v širšem kontekstu (kot izobraževalna segregacija, prostorska segregacija, družbena segregacija ali ekonomska segregacija), pogosto pa je povezan z mestnim nasiljem, kar odpira vprašanja o tem, kdaj in kako segregacija oblikuje nasilje v smislu trenj ali aktivnih konfliktov (Bhavnani idr., 2013; Trouille, 2014; Kutmanaliev, 2015; Ha, 2017; Zahnow, 2018). $\mathrm{Na}$ podlagi ključnih besed lahko raziskave razdelimo v štiri glavne tematske sklope: večkulturnost (družbeni pojavi, povezani z ustvarjanjem etnične raznolikosti), povezave (indeksi/parametri, ki merijo povezave med etničnimi identitetami ali med prostorom in identiteto), prostor ( $\mathrm{v}$ smislu javnega prostora ali skupnega dobra v prostorski obliki) in mesto (kot sistem omrežij, ki razkriva družbeno-prostorske odnose).

Povezave med članki tvorijo mrežo socitiranih člankov, ki kaže, kako se objave med seboj razlikujejo glede na socitirane vire. Socitiranje se nanaša na to, kako pogosto sta dva članka skupaj citirana v drugih člankih (Chen in Song, 2019). Za vsak grozd je navedena glavna tema, ki so jo obravnavali citirani avtorji. Navedena mreža vsebuje 16 grozdov socitiranih člankov, med katerimi je šest glavnih (slika 4). Citirani avtor ali raziskava sta lahko vključena v več grozdov hkrati. Posamezni grozdi vsebujejo med seboj povezane raziskave in/ali avtorje, kar razkriva najbolj značilne pristope k posamezni temi (slika 5). Pomembna so tudi žarišča citiranosti, ki kažejo, kateri članki v kratkem času pritegnejo veliko pozornost (Chen, 2016) oziroma so v izbranem obdobju najpogosteje citirani.

\subsubsection{Pojmovni grozd 1: povezava med človekom in krajem}

Tema največjega grozda (na sliki 4 označen kot št. 0) so migracije. Najpogosteje citirani avtor v njem je Amin (2012), ki obravnava etnično raznolikost in vlogo javnega prostora $\mathrm{v}$ mestu tujcev z vidika sodobne urbanistične politike čiščenja prostorov, na katerih sobivajo neželene skupine. Urbanistične politike upravljanja in spodbujanja družbene kohezije se lahko oblikujejo na podlagi proučevanja, kako se z etničnimi razlikami dnevno spoprijemajo v večkulturnih mestih. Število tovrstnih analiz pa je dokaj omejeno (Amin, 2002; Fincher in Iveson, 2008; Valentine, 2008). Razumevanje družbenih in prostorskih procesov, povezanih z raznolikimi vzorci rabe javnega prostora, je precej zapleteno in zahtevno. Kot razlaga Massey (1994: 168), je razlog lahko ta, da je koncept kraja sestavljen iz niza družbenih odnosov, ki se na neki lokaciji prepletajo. Po njegovem mnenju ni treba, da imajo kraji meje, ki jih ločujejo in zamejujejo (Massey, 1994: 155-156). Pogosto nimajo svoje identitete in je zanje značilno, da je veliko notranjih konfliktov, kar izhaja iz tega, da se na vsakem kraju zgošča posebna mešanica širših in lokalnih družbenih odnosov. Posledično so kraji progresivni in odprti navzven, sami sebe ne zamejujejo in niso vase zaprti (Massey 1994: 147).

Manjši grozd, katerega glavna tema je ustvarjanje kraja, se večinoma nanaša na delo Dona Mitchlla (2003), v katerem bralcu približa kritično trditev, da je treba pravico do mesta braniti z najrazličnejšimi oblikami raznolikosti, s čimer se lahko doseže socialna pravičnost. Njegova knjiga je tudi najpogosteje citirana objava (slika 6). Avtor zagovarja pomen mesta kot kraja raznolikosti in prizadevanj za ustvarjanje javne sfere (Mitchell, 2003: 18). Javni prostor opisuje kot fizično okolje, ki omogoča izraz posameznika ali skupine, $s$ čimer lahko pomembno prispeva $k$ ustvarjanju pravičnosti na ravni upravljanja. Če navedena pravičnost ni zagotovljena, manj opolnomočene skupine pogosto težko dostopajo do javnih prostorov in jih uporabljajo (Mitchell, 1995). Narašča zanimanje za migracije, azilno politiko, begunsko problematiko in podobno, kar je razvidno iz številnih študij primera, $\mathrm{v}$ katerih avtorji po vsem svetu proučujejo politične okvire in analizirajo družbenopolitične vplive etnične raznolikosti na mestnih območjih (Lees, 2003; Bryne, 2012; Bhavnani idr., 2013; Festić, 2015; Fredman, 2018). Članki se na splošno nanašajo na to, kako ljudje vsakodnevno doživljajo kulturno raznolikost in se z njo spoprijemajo v konkretnih situacijah (Wise in Velayutham, 2009: 2), avtorji pa predlagajo tudi novo politiko upravljanja raznolikosti, primerno za sedanji čas (Brown, 2006; Amin, 2012). Drugo najpogosteje citirano delo je članek Stevena Vertovca (2007), v katerem proučuje vzhodni London in Birmingham. Zaradi močnih postkolonialnih trendov priseljevanja v Združenem kraljestvu območji obravnava kot heterogeni, pri čemer se osredotoča na izkušnje priseljencev. Vpelje izraz superraznolikost (ang. super-diversity), ki upošteva različne identifikacije in osi razločevanja, med katerimi se samo nekatere nanašajo na etničnost (Vertovec 2007: 1048). Neenakost med etničnimi skupinami povzročajo še mnogi drugi dejavniki, na primer vera, družbeni razred, starost, spol in pravni status.

\subsubsection{Pojmovni grozd 2: odnosi med ljudmi}

Glavna tema drugega grozda (na sliki 4 označen kot št. 2) je posameznik in družba. Po definiciji so javni prostori univerzalno dostopni in nudijo eno redkih priložnosti za to, da se ljudje neposredno srečujejo z ljudmi, ki imajo drugačne navade in prihajajo iz drugih kultur (Shaftoe, 2008: 13). Lobova (2010) je najbolj citirana avtorica v tem grozdu, njena etnografska raziskava pa razkriva pomen navezanosti na kraj kot družbenopolitičnega dejavnika, ki se oblikuje skozi vsakdanje medkulturne stike na javnih mestih. Navedeno lahko zabriš̌e ustaljene etnične meje ter prispeva $\mathrm{k}$ medetničnemu razumevanju in občutku 


\begin{tabular}{|c|c|c|c|c|c|}
\hline Objave & Leto & Moć & Zaćetek. & Konec & $1995-2020$ \\
\hline Ruddick S, 1996, URBAN GEOGR, V17, P132, DOI 10,2747/0272-3638, 17,2,132, DOI & 1996 & 5.36 & 1999 & 2003 & \\
\hline Day K, 1999, ENVIRON PLANN D, V17, P307, DOI 10.1068/d170307, DOI & 1999 & 3.55 & 2003 & 2006 & \\
\hline Caldeirs Teresa, 2000, oITY WALLS CRIME SEG, VO, PO & 2000 & 3.48 & 2005 & 2008 & \\
\hline Mitchell D, 2003, RIGHT CITY SOCIAL JU, VO, PO & 2003 & 7.79 & 2006 & 2011 & \\
\hline Valentine G. 2008, PROG HUM GEOG, V32, P323, DOI 10.1177/0309133308089372, DOI & 2008 & 5.16 & 2011 & 2016 & \\
\hline Kaczynski AT, 2007, LEISURE SCI, V29, P315, DOI 10 1080/01490400701394865, DOI & 2007 & 3.83 & 2011 & 2014 & \\
\hline Venovec S. 2007 ETHNIC RACIAL, STUD, V30, P1024, DOI 10,1080/01419870701599465, DOI & 2007 & 5.66 & 2012 & 2015 & \\
\hline Cohen DA, 2007, AM J PUBLIC HEALTH, V97, P509, DOI 10.2105/A.JPH.2005.072447, DOI & 2007 & 3.36 & 2013 & 2014 & \\
\hline AMin A, 2012. LAND STRANGERS, VO, P0 & 2012 & 3.85 & 2014 & 2018 & \\
\hline Ariderson E, 2011, COSMOPOLITAN CANOPY, V0, PO & 2011 & 4.78 & 2015 & 2020 & \\
\hline
\end{tabular}

Slika 6: Prikaz najpogosteje citiranih objav, oblikovan v programu CiteSpace (ilustracija: avtorici)

pripadnosti (Lobo, 2010: 85). Številne raziskave obravnavajo podobne teme in pomen srečevanja na mestnem javnem prostoru. Wessel (2009: 7) navaja, da vsakodnevna izpostavljenost raznolikosti zmanjšuje predsodke. Bližina pa še ne pomeni, da imajo ljudje med sabo tudi pomembne stike. Tudi če si na javnem prostoru izmenjajo vljudnostne fraze, imajo lahko še vedno predsodke do pripadnikov etničnih manjšin (Piekut in Valentine, 2017: 177). Avtorica tretjega najpogosteje citiranega članka (Valentine, 2008) ugotavlja, da ni nujno, da pozitivna srečanja s pripadniki etničnih manjšin izboljšajo mnenja o teh skupinah (Valentine, 2008: 332). Podobno so tudi kvantitativne raziskave pokazale, da večja etnična raznolikost $\mathrm{v}$ javnem prostoru neposredno ne izboljša odnosov med ljudmi in njihovega vedenja (Piekut in Valentine, 2017: 177). Raziskovalci zato proučujejo, v katerih okoliščnah lahko etnična heterogenost povzroča trenja (Schlueter in Scheepers, 2010; Stolle idr., 2013; Laurence, 2014). Nekateri proučujejo vsakdanje odnose ljudi v javnem prostoru. Cattell idr. (2008: 556) ugotavljajo, da najrazličnejši javni odprti prostori pozitivno vplivajo na počutje posameznikov in celotne skupnosti. Rezultati njihove raziskave poudarjajo zlasti pomen skupne rabe javnih prostorov kot skupnih vrednot, ki lahko pomaga ohranjati zdravje in dobro počutje ljudi. Kažmierczakova (2013:31) je proučevala, kako lokalni parki prispevajo $\mathrm{k}$ razvoju socialnih vezi $\mathrm{v}$ treh soseskah v središču Manchestra, za katere so značilne različne ravni materialnega pomanjkanja in etnične raznolikosti. Avtorica ugotavlja, da se je treba poleg trenutne socialne sestave teh območij osredotočati tudi na kratkoročne spremembe $\mathrm{v}$ razporeditvi družbenih skupin $\mathrm{v}$ prostoru.

Objave v drugem pojmovnem grozdu torej kažejo, da lahko družbeni odnosi na socialno izoliranih območjih pomagajo premagati ali vsaj zmanjšati razlike (Amin, 2002). Osredotočajo se bodisi na odnose med večinskim prebivalstvom in etničnimi manjšinami bodisi na posamezno prevladujočo etnično skupino. Kot navaja Gehl (2011), intenzivnost stikov ni neposredno povezana z njihovim pomenom. $V$ primerjavi z drugimi oblikami stikov se zdijo manj intenzivni stiki nepomembni, vendar so dragoceni kot samostojne oblike stikov in tudi kot temeljni pogoji za druge, bolj kompleksne interakcije (Gehl,
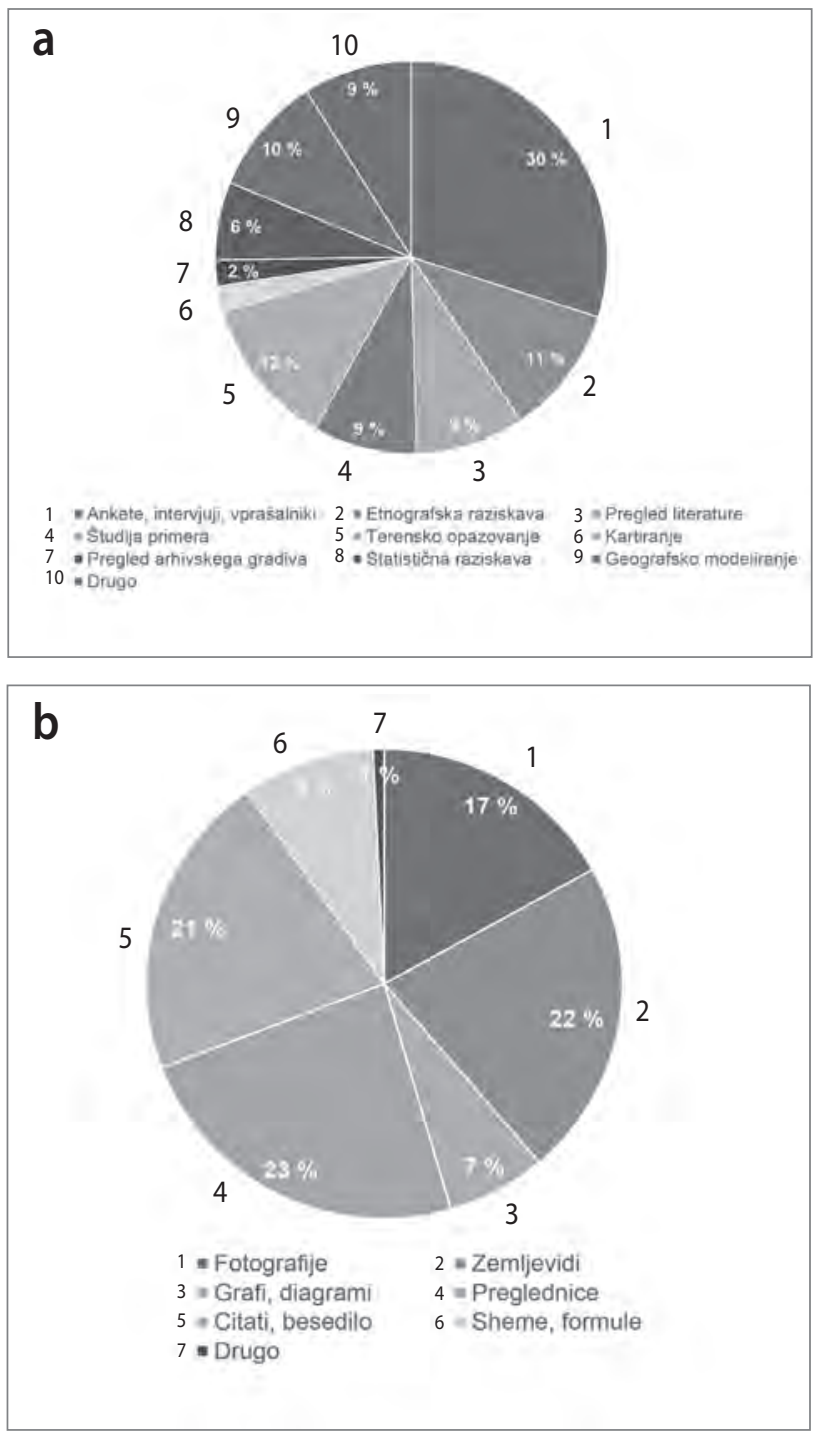

Slika 7: a) vrste uporabljenih metodologij (v odstotkih), b) način predstavitve podatkov, pridobljenih $\mathrm{z}$ uporabljenimi metodami $(\mathrm{v}$ odstotkih) (ilustracija: avtorici)

2011: 15). Čeprav raziskovalci uporabljajo različne pristope, se čedalje bolj osredotočajo na teoretiziranje o etničnih stikih na javnih prostorih in na proučevanje teh stikov. 


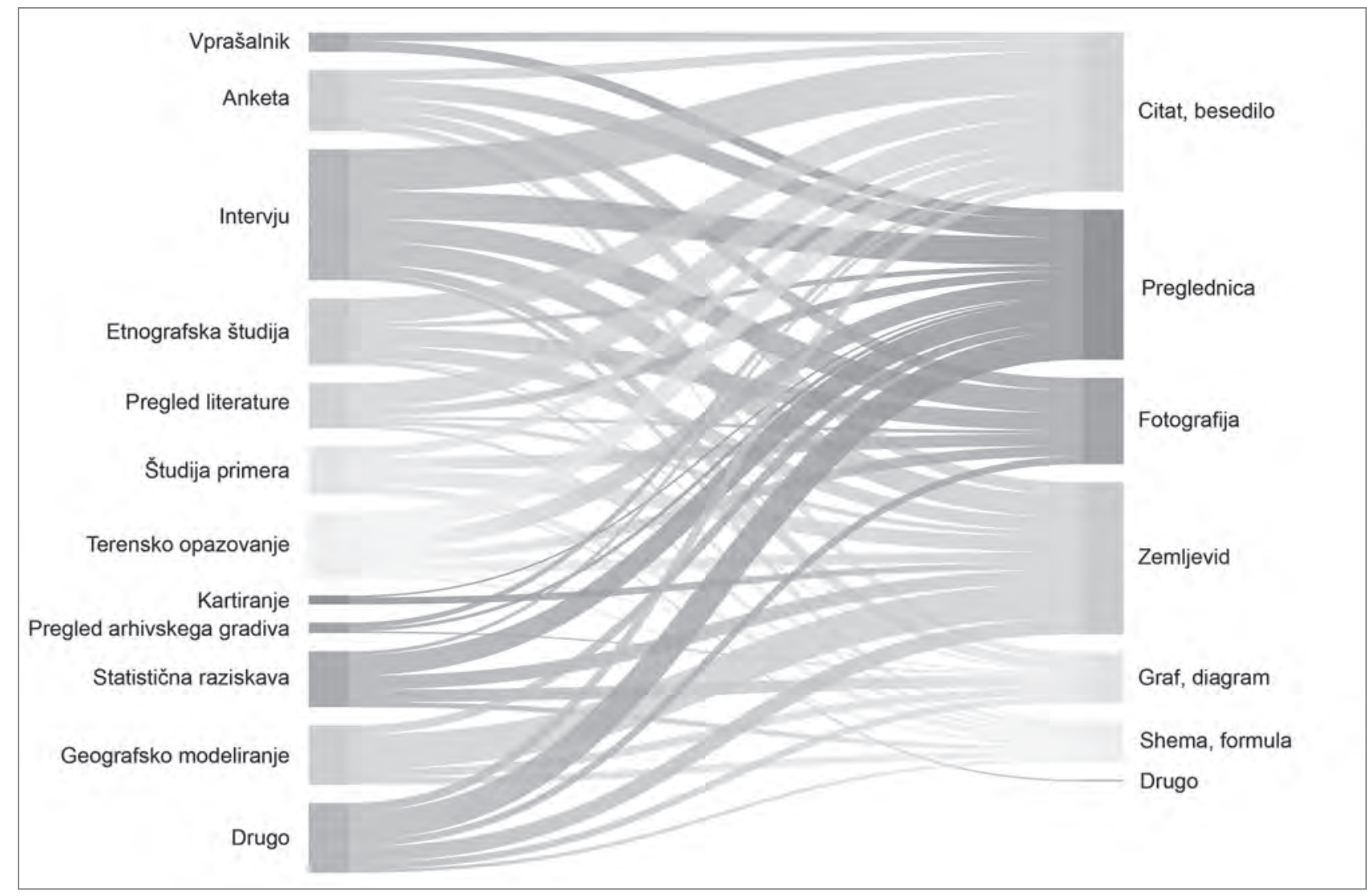

Slika 8: Povezava med uporabljenimi metodologijami in načinom predstavitve z njimi pridobljenih podatkov (ilustracija: avtorici)

\subsection{Metodološki pristopi}

Izkazalo se je, da kvalitativne raziskave razkrivajo pozitivne ali negativne vplive na javni prostor in preverjajo postavljene hipoteze, kvantitativne raziskave pa predstavljajo številske vrednosti proučevanih razmerij med pojavi na podlagi izbranih indeksov in parametrov. V nekaterih raziskavah avtorji uporabljajo tudi mešano metodo, kar pomeni, da proučujejo tako kvalitativne in kvantitativne podatke. Kvalitativni podatki so zbrani z intervjuji in anketami, raziskave pa se opirajo tudi na pregled literature in arhivskega gradiva. Rezultati kažejo, da v 138 člankih avtorji posebej omenjajo uporabo etnografske raziskovalne metode, dejansko pa je bila ta metoda uporabljena v približno polovici vseh raziskav (slika 7). Cilj etnografskih raziskav je razumeti kulture in norme $\mathrm{z}$ osredotočanjem na človekovo vedenje in zbiranjem opazovalnih podatkov (Creswell, 1998, 2003). Glede na to, da je skoraj četrtina vseh raziskav vključevala osebne pripovedi, pridobljene $\mathrm{v}$ intervjujih, je treba poudariti pomen participativnih metod. Kvantitativni podatki pa so bili pridobljeni iz statističnih podatkovnih zbirk, $s$ kartiranjem in terenskim opazovanjem. Pri zadnjenavedenem je bil poudarek na ugotavljanju vzorcev vsakdanjih aktivnosti uporabnikov javnih prostorov. Analize so se osredotočale na robne in manjše skupnosti v proučevanem urbanem naselju. Nekatere študije primera so obravnavale sta- novanjske soseske, predmestja in izobraževalna okolja, kot so gimnazije in univerzitetna študentska naselja ( $\mathrm{v}$ teh primerih so bile fokusne skupine sestavljene iz dijakov in študentov).

Avtorici sta nato podrobneje proučili še povezavo med uporabljeno metodo in načinom predstavitve pridobljenih podatkov. Skoraj pri vseh vrstah metodoloških pristopov so bili podatki predstavljeni v obliki besedila, precejšen delež podatkov pa je bil predstavljen tudi vizualno, v obliki fotografij ali zemljevidov (slika 8).

\section{Sklep}

Razumevanje medetničnih odnosov na javnih prostorih z različnih vidikov je ključni dejavnik, ki preprečuje poslabšanje socialne klime. Raziskava razkriva, da se večina literature $s$ proučevanega področja navezuje na geografijo, urbanizem in sociologijo, pri čemer so izbrane objave povezane z najrazličnejšimi podpodročji. Raziskave obravnavajo štiri glavne teme: večkulturnost, povezave, prostor in mesto. Z bibliometrično analizo sta bila določena dva glavna grozda socitiranosti, ki sta bila analizirana z vidika naštetih tem. Grozdi razkrivajo povezave med človekom in krajem (družbeno-prostorske povezave) in med ljudmi (družbeno-psihološke povezave). 
Največji grozd se nanaša na povezave med človekom in krajem ter se osredotoča na etnično raznolikost kot pomemben dejavnik pri oblikovanju urbanistične in socialne politike. Študije primera $\mathrm{v}$ tem grozdu obravnavajo družbenopolitične vplive in prizadevanja, zlasti v povezavi z migracijami, azilno politiko in begunsko problematiko. Pojem kraja je obravnavan kot skupno dobro, ki omogoča razvoj kolektivne in individualne javne podobe. $\mathrm{V}$ drugem grozdu je javni prostor platforma za uresničevanje družbenih odnosov in $s$ tem kraj srečevanja različnih etničnih skupin. Proučevanje tega, kako se različne etnične skupine obnašajo $\mathrm{v}$ javnem prostoru, pa je večinoma še vedno na zelo osnovni ravni. Empirične raziskave so pokazale, da so lokalni vplivi etnične izraženosti pomembni za razumevanje dejavnikov, ki določajo družbene odnose na stanovanjskih območjih. V večini raziskav je pri analizi vedenj v javnem prostoru etničnost preprosto obravnavana kot sospremenljivka, glavni poudarek pa je na razlikah med skupinami, zlasti na razmerju med večinsko etnično skupino in manjšinskimi skupinami v skupnosti. V literaturi je v tem pogledu javni prostor obravnavan kot kraj tekmovanja, nasprotovanj ali pogajanj. Povezave med grozdi kažejo, da če pravičnost ni zagotovljena na upravni ravni, socialno ogrožene etnične skupine le težko dostopajo do javnih prostorov in jih uporabljajo. Uporaba interdisciplinarnega pristopa k proučevanju večetničnih naselij lahko zato spodbudi razprave o vprašanjih, pomembnih za oblikovanje politike ter zagotavljanje miru na lokalni in globalni ravni.

\section{Tülay Zıvalı Turhan}

Univerza Jildirima Bejazita v Ankari, Fakulteta za arhitekture in likovno umetnost, Oddelek za arhitekturo, Ankara, Turčija

E-naslov: tturhan@ybu.edu.tr

Hatice Ayataç

Tehnična univerza v Istanbulu, Fakulteta za arhitekturo, Oddelek za urbanizem in regionalno načrtovanje, Istanbul, Turčija

E-naslov: ayatac@itu.edu.tr

\section{Viri in literatura}

Aharon-Gutman, M. (2014): The iron cage of ethnicity: Ethnic urban enclaves and the challenge of urban design. Urban Design International, 19(1), str. 144-158. DOI: 10.1057/udi.2013.20

Amin, A. (2002): Ethnicity and the multicultural city: Living with diversity. Environment and Planning, 34(6), str. 959-980. DOI: 10.1068/a3537

Amin, A. (2012): Land of strangers. Cambridge, Polity.

Andrade, L. F. S., de Pavia, A. L., de Brito, M. J., Garcia, A. S., in do Prado, J. W. (2016): The right to shape different cities and public realm? A systematic review on "right to the city" scientific production in public administration (1995-2015). Prispevek je bil predstavljen na konferenci XL Encontro do ANPAD, ki je potekala od 25. do 28. septembra v Costi do Sauípe v Braziliji. Tipkopis.
Ayata, S. (2008): Migrants and changing urban periphery: Social relations, cultural diversity and the public space in Istanbul's new neighbourhoods. International Migration, 46(3), str. 27-64. DOI: 10.1111/j.1468-2435.2008.00461.x

Back, L. (2015): Why everyday life matters: Class, community and making life liveable. Sociology, 49(5), str. 820-836. DOI: $10.1177 / 0038038515589292$

Badarin, E. (2015): Settler-colonialist management of entrances to the native urban space in Palestine. Settler Colonial Studies, 5(3), str. 226235. DOI: 10.1080/2201473X.2014.955946

Bhavnani, R. Donnay, K., Miodownik, D., Mor, M., in Helbing, D. (2013): Group segregation and urban violence. American Journal of Political Science, 58(1), str. 226-245. DOI: 10.1111/ajps.12045

Blumer, M., in Solomos, J. (2015): Multiculturalism, social cohesion and immigration. London, Routledge.

Brown, J. M. (2006): Global South Asians: Introducing the modern diaspora. Cambridge, Cambridge University Press.

DOI: $10.1017 / C B O 9780511807657$

Bryne, J. (2012): When green is white: The cultural politics of race, nature and social exclusion in a Los Angeles urban national park. Geoforum, 43(3), str. 595-611. DOI: 10.1016/j.geoforum.2011.10.002

Burgers, J., in Zuiderwijk, L. (2016): At home at the neighborhood square. Home Cultures, 13(2), str. 101-121. DOI: 10.1080/17406315.2016.1190582

Caliendo, G. G. (2011): MLK Boulevard: Material forms of memory and the social contestation of racial signification. Journal of Black Studies, 42(7), str. 1148-1170. DOI: 10.1177/0021934711404415

Carmona, M., Heath, T., Oc, T., in Tiesdell, S. (2003): Public spaces - urban spaces. Oxford, The Architectural Press.

Cattell, V., Dines, N., Gesler, W., in Curtis, S. (2008): Mingling, observing, and lingering: Everyday public spaces and their implications for well-being and social relations. Health \& Place, 14(3), str. 544-561. DOI: 10.1016/j.healthplace.2007.10.007

Charambous Antoniadou, N., in Peristianis, N. (2001): Ethnic groups, space, and identity. V: Peponis, J., Wineman, J., in Bafna, S. (ur.): Space syntax: 3rd international symposium, Georgia Institute of Technology, Atlanta, May 7-11 2001: Proceedings. Ann Arbor, A. Alfred Taubman College of Architecture and Urban Planning.

Chen, C. (2016): CiteSpace: A practical guide for mapping scientific literature. New York, Nova Science Publishers.

Chen, C. (2020): How to use CiteSpace. Victoria, Lean Publishing.

Chen C., in Song, M. (2019): Visualizing a field of research: A methodology of systematic scientometric reviews. PLOS ONE, 14(10), e0223994. DOI: 10.1371/journal.pone.0223994

Chuang, R.-J., Sharma, S., Skala, K., in Evans, A. (2013): Ethnic differences in the home environment and physical activity behaviors among low-income, minority preschoolers in Texas. American Journal of Health Promotion, 27(4), str. 270-278. DOI: 10.4278/ajhp.110427-QUAN-171

Creswell, J. W. (1998): Qualitative inquiry and research design: Choosing among five traditions. Thousand Oaks, CA, Sage.

Creswell, J. W. (2003): Research design: Qualitative, quantitative and mixed methods approaches. Thousand Oaks, CA, Sage.

Demintseva, E. (2017): Labour migrants in post-Soviet Moscow: Patterns of settlement. Journal of Ethnic and Migration Studies, 43(15), str. 2556-2572. DOI: 10.1080/1369183X.2017.1294053 
Dines, N., Cattell, V., Gesler, W., in Curtis, S. (2006): Public spaces, social relations and well-being in East London. Bristol, Policy Press.

Ehrkamp, P. (2013): "I've had it with them!" Younger migrant women's spatial practices of conformity and resistance. Gender, Place \& Culture, 20(1), str. 19-36. DOI: 10.1080/0966369X.2011.649356

Ferati, A. (2009): Spatial and ethnic patterns: The interface between "majority" and "minority" in Macedonia. V: Koch, D., Marcus, L., in Steen, J. (ur.): Proceedings of the 7th International Space Syntax Symposium. Stockholm, KTH.

Festić, F. (2015): Coming to terms with horror: The "ghosts" of the 'ex-Yugoslav' wars and psycho-politics after communism. Chinese Semiotic Studies, 11(2), str. 181-203. DOI: 10.1515/css-2015-0010

Fincher, R., in Iveson, K. (2008): Planning and diversity in the city. London, Palgrave Macmillan. DOI: 10.1007/978-1-137-06960-3

Fredman, A. (2018): Perfectionist public space: A political philosophy approach. Space and Polity, 22(1), str. 30-49.

DOI: 10.1080/13562576.2018.1485216

Gehl, J. (2011): Life between buildings: Using public space. Washington, $\mathrm{DC}$, Island Press.

Gehl, J., in Gemzoe, L. (1996): Public spaces - Public life. København, Danish Architectural Press.

Gibson, D. (2018): When empathy is not enough: A reflection on the self-experience of black boys in public spaces. Pastoral Psychology, 67(1), str. 611-626. DOI: 10.1007/s11089-018-0837-x

Hall, S. M. (2015): Super-diverse street: A "trans-ethnography" across migrant localities. Ethnic and Racial Studies, 38(1), str. 22-37. DOI: 10.1080/01419870.2013.858175

Harwood, S. A., Mendenhall, R., Lee, S. S., Riopelle, C., in Huntt, M. B. (2018): Everyday racism in integrated spaces: Mapping the experiences of students of color at a diversifying predominantly white institution. Annals of the American Association of Geographers, 108(5), str. 12451259. DOI: $10.1080 / 24694452.2017 .1419122$

Hillier, B. (1996): Space is the machine: A configurational theory of architecture. Cambridge, Cambridge University Press.

Hillier, B., Penn, A., Hanson, J., Grajevski, T., in Xu, J. (1993): Natural movement: Or, configuration and attraction in urban pedestrian movement. Environment \& Planning B: Planning \& Design, 20(1), str. 29-66. DOI: $10.1068 / \mathrm{b} 200029$

Ha, H. J. (2017): Emotions of the weak: Violence and ethnic boundaries among Coptic Christians in Egypt. Ethnic and Racial Studies, 40(1), str. 133-151. DOI: 10.1080/01419870.2016.1201586

Ho, C.-H., Sasidharan, V., Elmendorf, W., Willits, F. K., Graefe, A., in Godbey, G. (2005): Gender and ethnic variations in urban park preferences, visitation, and perceived benefits. Journal of Leisure Research, 37(3), str. 281-306. DOI: 10.1080/00222216.2005.11950054

Hopkins, P., Botterill, K., Sanghera, G., in Arshad, R. (2017): Encountering misrecognition: Being mistaken for being Muslim. Annals of the American Association of Geographers, 107(4), str. 934-948.

DOI: 10.1080/24694452.2016.1270192

Hutchinson, J., in Smith, A. D. (1996): Ethnicity. Oxford, Oxford University Press.

Jacobs, J. (1961): The death and life of great American cities. New York, Random House.

Jackson, E. (2019): Valuing the bowling alley: Contestations over the preservation of spaces of everyday urban multiculture in London. The Sociological Review, 67(1), str. 79-94. DOI: 10.1177/0038026118772784
Jadallah, D. (2014): Colonialist construction in the urban space of Jerusalem. Middle East Journal, 68(1), str. 77-98. DOI: 10.3751/68.1.14

Johnson, A. M., in Miles, R. (2014): Toward more inclusive public spaces: Learning from the everyday experiences of Muslim Arab women in New York City. Environment and Planning A: Economy and Space, 46(8), str. 1892-1907. DOI: 10.1068/a46292

Joly, D. (2017): Women from Muslim communities: Autonomy and capacity of action. Sociology, 51(4), str. 816-832. DOI: $10.1177 / 0038038515621677$

Kaczynski, A. T., Stanis, S. A., Besenyi, G. M., in Child, S. (2013): Differences in youth and adult physical activity in park settings by sex and race/ethnicity. Preventing Chronic Disease, 10, E42. DOI: $10.5888 /$ pcd10.120276

Kažmierczak, A. (2013): The contribution of local parks to neighbourhood social ties. Landscape and Urban Planning, 109(1), str. 31-44. DOI: 10.1016/j.landurbplan.2012.05.007

Khoo, C. S. G., Na, J., in Jaidka, K. (2010): Analysis of the macro-level discourse structure of literature reviews. Online Information Review, 35(2), str. 255-271. DOI: 10.1108/14684521111128032

Kloek, M. E., Peters, K., in Sijtsma, M. (2013): How Muslim women in the Netherlands negotiate discrimination during leisure activities. Leisure Sciences, 35(5), str. 405-421. DOI: 10.1080/01490400.2013.831285

Kutmanaliev, J. (2015): Public and communal spaces and their relation to the spatial dynamics of ethnic riots: Violence and non-violence in the city of Osh. International Journal of Sociology and Social Policy, 35(7/8), str. 449-477. DOI: 10.1108/IJSSP-02-2015-0027

Laurence, J. (2014): Reconciling the contact and threat hypotheses: Does ethnic diversity strengthen or weaken community inter-ethnic relations? Ethnic and Racial Studies, 37(8), str. 1328-1349. DOI: $10.1080 / 01419870.2013 .788727$

Le Gentil, E., in Mongruel, R. (2014): A systematic review of socio-economic assessments in support of coastal zone management (1992-2011). Journal of Environmental Management, 149(1), str. 85-96. DOI: 10.1016/j.jenvman.2014.10.018

Lees, L. (2003): The ambivalence of diversity and the politics of urban renaissance: The case of youth in downtown Portland, Maine. International Journal of Urban and Regional Research, 27(3), str. 613-634. DOI: 10.1111/1468-2427.00469

Lobo, M. (2010): Interethnic understanding and belonging in suburban Melbourne. Urban Policy and Research, 28(1), str. 85-99. DOI: 10.1080/08111140903325424

Lobo, M. (2014): Everyday multiculturalism: Catching the bus in Darwin, Australia. Social \& Cultural Geography, 15(7), str. 714-729. DOI: 10.1080/14649365.2014.916743

Lobo, M. (2015): Gestures of judgement and welcome in public spaces: Hypervisible migrant newcomers in Darwin, Australia. Journal of Cultural Geography, 32(1), str. 54-67. DOI: 10.1080/08873631.2015.1005881

Loukaitou-Sideris, A. (1995): Urban form and social context: cultural differentiation in the uses of urban parks. Journal of Planning Education and Research, 14(2), str. 89-102. DOI: 10.1177/0739456X9501400202

Massey, D. (1994): Space, place and gender. Cambridge, Polity Press.

Mitchell, D. (1995): The end of public space? People's park, definitions of the public, and democracy. Annals of the Association of American Geographers, 85(1), str. 108-133.

Mitchell, D. (2003): The right to the city: Social justice and the fight for public space. New York, Guilford Press. 
Mohammad, R. (2013): Making gender ma(r)king place: Youthful British Pakistani Muslim women's narratives of urban space. Environment and Planning A: Economy and Space, 45(8), str. 1802-1822. DOI: 10.1068/a45253

Monterescu, D. (2011): Estranged natives and indigenized immigrants: A relational anthropology of ethnically mixed towns in Israel. World Development, 39(2), str. 270-281. DOI: 10.1016/j.worlddev.2009.11.027

Müller, T. (2011): Interethnic interactions and perceptions of immigrant men in public space: The experience of community safety by seniors in a multicultural neighbourhood. V: Denzin, N. K., in Faust, T. (ur.) Studies in Symbolic Interaction, str. 63-78. Bingley, Emerald Group Publishing. DOI: 10.1108/S0163-2396(2011)0000037005

Omer, I., Goldblatt, R., Romann, M., in Khamaisi, R. (2018): Tolerance, intergroup contacts and municipal-spatial organisation: The case of Jews and Arab Palestinians in the Tel-Aviv metropolitan area. Tijdschrift voor Economische en Sociale Geografie, 109(1), str. 57-72. DOI: 10.1111/tesg.12259

Peoples, J. G., in Bailey, G. (2011): Humanity: An introduction to cultural anthropology. Boston, Wadsworth Publishing.

Piekut, A., in Valentine, G. (2017): Spaces of encounter and attitudes towards difference: A comparative study of two European cities. Social Science Research, 62(1), str. 175-188.

DOI: 10.1016/j.ssresearch.2016.08.005

Rigolon, A., in Németh, J. (2018): Privately owned parks in New Urbanist communities: A study of environmental privilege, equity, and inclusion. Journal of Urban Affairs, 40(4), str. 543-559.

DOI: $10.1080 / 07352166.2017 .1360739$

Rishbeth, C., Ganji, F., in Vodicka, G. (2018): Ethnographic understandings of ethnically diverse neighbourhoods to inform urban design practice. Local Environment, 23(1), str. 36-53.

DOI: 10.1080/13549839.2017.1385000

Rokem, J., in Vaughan, L. (2018): Segregation, mobility and encounters in Jerusalem: The role of public transport infrastructure in connecting the "divided city". Urban Studies, 55(15), str. 3454-3473. DOI: $10.1177 / 0042098017691465$

Rollock, N., Gillborn, D., Vincent, C., in Ball, S. (2011): The public identities of the black middle classes: Managing race in public spaces. Sociology, 45(6), str. 1078-1093. DOI: 10.1177/0038038511416167

Ryan, L. (2003): Moving spaces and changing places: Irish women's memories of emigration to Britain in the 1930s. Journal of Ethnic and Migration Studies, 29(1), str. 67-82. DOI: 10.1080/1369183032000076722

Schlueter, E., in Scheepers, P. (2010): The relationship between outgroup size and anti-outgroup attitudes: A theoretical synthesis and empirical test of group threat- and intergroup contact theory. Social Science Research, 39(2), str. 285-295. DOI: 10.1016/j.ssresearch.2009.07.006

Schmidt, G. (2012): "Grounded" politics: Manifesting Muslim identity as a political factor and localized identity in Copenhagen. Ethnicities, 12(5), str. 603-622. DOI: 10.1177/1468796811432839

Schmidt, S. J. (2015): A queer arrangement of school: Using spatiality to understand inequity. Journal of Curriculum Studies, 47(2), str. 253-273.

Sennett, R. (2003): The fall of public man. London, Penguin Books Ltd.

Shaftoe, H. (2008): Convivial urban spaces: Creating effective public spaces. Abingdon, Routledge.

Shtern, M. (2016): Urban neoliberalism vs. ethno-national division: The case of West Jerusalem's shopping malls. Cities, 52(1), str. 132-139. DOI: 10.1016/j.cities.2015.11.019
Shuangyun, Y., in Hongxia, L. (2020): Knowledge mapping of ethnic identity and acculturation based on the method of bibliometric. Journal of Ethnic and Cultural Studies, 7(3), str. 17-33.

DOI: $10.29333 /$ ejecs/370

Shuval, K., Weissblueth, E., Brezis, M., Araida, A., in DiPietro, L. (2009): Individual and socioecological correlates of physical activity among Arab and Jewish college students in Israel. Journal of Physical Activity and Health, 6(3), str. 306-314. DOI: 10.1123/jpah.6.3.306

Stavrides, S. (2016): Common space: The city as commons. London, Zed Books. DOI: 10.5040/9781350219267

Stolle, D., Petermann, S., Schmid, K., Schönwälder, K. Hewstone, M., Vertovec, S., idr. (2013): Immigration-related diversity and trust in German cities: The role of intergroup contact. Journal of Elections, Public Opinion and Parties, 23(3), str. 279-298. DOI: 10.1080/17457289.2013.809350

$\mathrm{Su}, \mathrm{X} ., \mathrm{Li}, \mathrm{X}$., in Yanxin, K. (2019): A bibliometric analysis of research on intangible cultural heritage using CiteSpace. SAGE Open, April 2019, str. 1-18. DOI: $10.1177 / 2158244019840119$

Swyngedouw, E. (2013): The segregation of social interactions in the Red Line L-Train in Chicago. Symbolic Interaction, 36(1), str. 293-313. DOI: 10.1002/symb.64

Triandafyllidou, A., in Kouki, H. (2013): Muslim immigrants and the Greek nation: The emergence of nationalist intolerance. Ethnicities, 13(6), str. 709-728. DOI: 10.1177/1468796813483287

Trouille, D. (2014): Fencing a field: Imagined others in the unfolding of a neighborhood park conflict. City \& Community, 13(1), str. 69-87. DOI: 10.1111/cico.12052

Valentine, G. (2008): Living with difference: Reflections on geographies of encounters. Progress in Human Geography, 32(3), str. 323-337. DOI: $10.1177 / 0309133308089372$

Vaughan, K. B., Kaczynski, A. T., Wilhelm Stanis, S. A., Besenyi, G. M., Bergstrom, R., in Heinrich, K. M. (2013): Exploring the distribution of park availability, features, and quality across Kansas City, Missouri by income and race/ethnicity: An environmental justice investigation. Annals of Behavioral Medicine, 45(1), str. S28-S38. DOI: 10.1007/s12160-012-9425-y

Vertovec, S. (2007): Super-diversity and its implications. Ethnic and Racial Studies, 30(6), str. 1024-1054. DOI: 10.1080/01419870701599465

Wessel, T. (2009): Does diversity in urban space enhance intergroup contact and tolerance? Geografiska Annaler: Series B, Human Geography, 91(1), str. 5-17. DOI: 10.1111/j.1468-0467.2009.00303.x

Whyte, W. H. (1980): The social life of small urban spaces. New York, Project for Public Spaces.

Williamson, R. (2016): Everyday space, mobile subjects and place-based belonging in suburban Sydney. Journal of Ethnic and Migration Studies, 42(14), str. 2328-2344. DOI: 10.1080/1369183X.2016.1205803

Wilson, T. S. (2016): Contesting the public school: Reconsidering charter schools as counterpublics. American Educational Research Journal, 53(4), str. 919-952. DOI: 10.3102/0002831216658972

Wise, A., in Velayutham, S. (ur.) (2009): Everyday multiculturalism. London, Palgrave Macmillan. DOI: 10.1057/9780230244474

Wolch, J., Wilson, J. P., in Fehrenbach, J. (2005): Parks and park funding in Los Angeles: An equity-mapping analysis. Urban Geography, 26(1), str. 4-35. DOI: 10.2747/0272-3638.26.1.4

Yiftachel, O., in Yacobi, H. (2003): Urban ethnocracy: Ethnicization and the production of space in an Israeli "mixed city". Environment and Planning D: Society and Space, 21(6), str. 673-693. DOI: 10.1068/d47j 
Yu, S., Bryant, M., Messmer, E., Tsagronis, S., in Link, S. (2018): "Is there a bubble to burst?" -College students' spatial perception of campus and the city: A case study of Rhodes College in Memphis, TN. Urban Geography, 39(10), str. 1555-1575. DOI: 10.1080/02723638.2018.1481602

Zahnow, R. (2018): Mixed land use: Implications for violence and property crime. City \& Community, 17(4), str. 1119-1142.

DOI: $10.1111 /$ cico.12337

Zsolt Farkas, J., Lennert, J., Donát Kovács, A., in Kanalas, I. (2017): Impacts and consequences of residential segregation of Roma in urban spaces: Case studies from Hungary. Urbani izziv, 28(2), str. 136-148. DOI: 10.5379/urbani-izziv-en-2017-28-02-005 